\title{
Gambaran magnesium serum pada pekerja bangunan
}

\author{
${ }^{1}$ Gloria N. L. Mudeng \\ ${ }^{2}$ Michaela E. Paruntu \\ ${ }^{3}$ Youla A. Assa
}

\author{
${ }^{1}$ Kandidat Skripsi Fakultas Kedokteran Unversitas Sam Ratulangi Manado \\ ${ }^{2}$ Bagian Biokimia Fakultas Kedokteran Universitas Sam Ratulangi Manado \\ Email: glorianandika@gmail.com
}

\begin{abstract}
Magnesium is one of the makroelemen body needs in large quantities and the fourth most electrolyte in the body. Vigorous activity could lead to change magnesium levels. The aim of this study was to determine the serum magnesium levels in construction workers. The study was conducted in a descriptive cross sectional arrangement with thirty respondents who were eligible to the inclusion criteria. Samples were taken using a total sampling methods. The results showed 29 respondents $(96,67 \%)$ with a normal serum magnesium levels of 1,6-2,6 $\mathrm{mg} / \mathrm{dL}$ and 1 repondent $(3,33 \%)$ with low serum magnesium levels. Conclusion: Most of the serum magnesium levels in construction workers are in normal limits.
\end{abstract}

Keywords: serum magnesium levels, construction workers, vigorous activity.

\begin{abstract}
Abstrak : Magnesium merupakan salah satu makroelemen yang dibutuhkan tubuh dalam jumlah besar dan merupakan elektrolit keempat terbanyak dalam tubuh. Aktivitas fisik berat dapat merubah kadar magnesium dalam tubuh. Tujuan penelitian ini adalah untuk mengetahui gambaran kadar magnesium serum pada pekerja bangunan. Penelitian bersifat deskriptif dengan pendekatan potong lintang dengan sampel berjumlah 30 orang sesuai dengan kriteria inklusi. Metode pemilihan sampel menggunakan cara total sampling. Hasil penelitian dengan nilai rujukan normal 1,6-2,6 mg/dL didapat 29 orang $(96,67 \%)$ dengan kadar normal dan 1 orang $(3,33 \%)$ dengan kadar magnesium serum rendah. Simpulan: Sebagian besar kadar magnesium serum pada pekerja bangunan ada dalam batas normal.

Kata kunci: kadar magnesium serum, pekerja bangunan, aktivitas fisik berat.
\end{abstract}

Makroelemen merupakan mineral yang dibutuhkan oleh tubuh dalam jumlah yang besar. Salah satu makroelemen yang paling banyak ditemukan di dalam tubuh yaitu magnesium. ${ }^{1}$ Magnesium merupakan elektrolit ion positif (kation) yang ada di cairan ekstraseluler dan termasuk keempat yang terbanyak dan penting bagi tubuh. Sebagian besar magnesium terdapat di dalam sel, sehingga menjadi kation intraselular terbanyak kedua setelah kalium, dan memiliki peranan vital pada fungsi selular normal. ${ }^{2}$ Kadar normal magnesium serum dalam tubuh yaitu 1,6-
$2,6 \mathrm{mg} / \mathrm{dL}$.

Kurangnya kadar magnesium dalam tubuh bisa disebabkan oleh beberapa faktor yaitu usia yang tua, absorpsi di usus yang menurun dan ekskresi yang meningkat. ${ }^{3}$ Kurangnya magnesium dalam darah disebut hipomagnesemia. Hipomagnesemia kronik memiliki manifestasi klinik yaitu tremor, agitasi, hipokalemia, bahkan bisa terjadi aritmia jantung. ${ }^{4}$

Jika kadar magnesium dalam darah jumlahnya berlebihan maka disebut hipermagnesemia. Hipermagnesemia yang simptomatik terjadi karena asupan 
magnesium yang berlebihan, terutama melalui konsumsi obat seperti laksatif. Biasanya peningkatan serum magnesium karena mengonsumsi magnesium berbentuk larutan magnesium sulfat dapat menimbulkan gejala seperti hipotensi, mual, dan muntah. ${ }^{4}$

Magnesium memiliki fungsi penting dalam pembentukan energi dalam tubuh karena magnesium berperan dalam pembentukan ATP, sehingga dengan tingginya aktivitas fisik seseorang, memungkinkan untuk merubah konsentrasi magnesium dalam tubuh. ${ }^{5}$

Aktivitas fisik merupakan gerakan yang dilakukan tubuh dan didukung oleh sistem muskuloskeletal dan memerlukan pengeluaran energi. ${ }^{6}$ Aktivitas fisik berat merupakan aktivitas yang memerlukan energi yang lebih banyak daripada aktivitas ringan dan sedang, serta memerlukan kekuatan otot yang lebih besar, seperti pekerjaan yang dilakukan oleh pekerja bangunan, contohnya dengan mengangkat beban berat, naik turun beberapa lantai setiap hari, mengaduk semen, dan lainnya. ${ }^{6}$

Menurut Rayssiquier at al, kadar magnesium plasma pada orang yang melakukan aktivitas fisik berat dalam jangka waktu yang panjang akan menurun dan akan memperburuk keadaan seseorang dengan defisiensi magnesium. ${ }^{7}$ Penelitian lain yang diadakan oleh Deuster et al, menyatakan arah dan besarnya redistribusi magnesium dalam sirkulasi dipengaruhi oleh intensitas latihan yang sudah dilakukan, semakin besar kebutuhan energi dari anaerobik atau metabolisme glikolitik, semakin besar translokasi magnesium dari plasma ke dalam sel darah merah. ${ }^{8}$

Berdasarkan latar belakang di atas, dijelaskan bahwa aktivitas fisik dengan intensitas berat dapat memengaruhi kadar magnesium serum. Karena alasan tersebut, peneliti tertarik untuk mengetahui gambaran magnesium serum pada pekerja bangunan.

\section{METODE PENELITIAN}

Penelitian merupakan penelitian deskriptif dengan pendekatan cross sectional (potong lintang) yang dilaksanakan pada bulan September 2016 sampai Desember 2016. Sampel penelitian yaitu pekerja bangunan di Fakultas Kedokteran Universitas Sam Ratulangi. Sampel diambil dengan metode total sampling dan berjumlah 30 orang. Variabel penelitian yaitu kadar magnesium serum yang diambil melalui darah vena dan aktifitas fisik intensitas berat.

\section{HASIL PENELITIAN}

Seluruh responden yaitu pria yang berusia antara 17-51 tahun yang totalnya berjumlah 30 orang dan setelah dilakukan pengambilan darah dan pengukuran kadar serum magnesium dalam darah sampel, didapatkan hasil 29 sampel (96,67\%) menunjukan kadar magnesium serum yang normal dan 1 sampel $(3,33 \%)$ menunjukan penurunan kadar magnesium serum.

Tabel 1. Distribusi Responden Berdasarkan Hasil Kadar Magnesium Serum

\begin{tabular}{ccc}
\hline $\begin{array}{c}\text { Kadar Magnesium } \\
\text { Serum }(\mathbf{m g} / \mathbf{d L})\end{array}$ & (n) & $\mathbf{( \% )}$ \\
\hline Rendah $(<1,6 \mathrm{mg} / \mathrm{dL})$ & 1 & 3,33 \\
Normal $(1,6-2,6$ & & \\
$\mathrm{mg} / \mathrm{dL})$ & 29 & 96,67 \\
Tinggi $(>2,6 \mathrm{mg} / \mathrm{dL})$ & 0 & 0 \\
Total & 30 & 100 \\
\hline
\end{tabular}

\section{BAHASAN}

Penelitian untuk mengetahui gambaran kadar magnesium serum dengan jumlah responden 30 orang dilakukan pada buruh yang bekerja di Fakultas Kedokteran Sam Ratulangi didapatkan satu orang $(3,33 \%)$ dengan kadar magnesium rendah atau disebut hipomagnesemia dan 29 orang atau 96,67\% dengan kadar magnesium serum normal. Responden adalah buruh bangunan yang melakukan aktivitas fisik berat.

Hasil penelitian ini di mana sebagian besar responden memiliki kadar magnesium serum normal setelah melakukan aktivitas fisik berat, bisa terjadi karena asupan makanan yang mengandung magnesium cukup dan ekskresi yang normal. ${ }^{9}$ Didapatkan melalui kuesioner, 
responden tidak memiliki penyakit yang bisa menyebabkan magnesium serum dalam tubuh rendah. ${ }^{10}$ Hasil ini berbeda dengan penelitian yang dilakukan di bagian biokimia FK Unsrat oleh Rompas GR et al pada tahun 2015, pada penelitian tersebut didapatkan kadar magnesium turun pada responden yang diberi perlakuan aktivitas fisik berat. ${ }^{11}$

Pada penelitian ini terdapat satu orang $(3,33 \%)$ memiliki kadar magnesium serum yang rendah. Kadar magnesium yang rendah bisa terjadi akibat aktivitas fisik. Aktifitas fisik yang berat dapat menyebabkan kadar magnesium rendah, kerena dengan aktifitas fisik yang berat dibutuhkan semakin banyak ATP sebagai energi untuk otot, dan magnesium berperan penting dalam metabolisme ATP, sehingga semakin banyak ATP yang diperlukan akibat semakin beratnya aktivitas fisik maka semakin banyak magnesium yang diperlukan, karena magnesium diperlukan untuk berikatan dengan ATP menjadi ADP dan nantinya akan digunakan untuk menjadi energi bagi tubuh. ${ }^{12}$ Hasil penelitian yang dilakukan sesuai dengan penelitian oleh Rayssiguier at al yang menyebutkan bahwa kadar magnesium pada orang yang melakukan latihan fisik dalam jangka waktu lama akan mengalami penurunan. $^{7}$ Menurut penelitian oleh Deuster et al, arah dan besarnya redistribusi magnesium dalam sirkulasi dipengaruhi oleh intensitas latihan yang sudah dilakukan, semakin besar kebutuhan energi dari anaerobik atau metabolisme glikolitik, semakin besar translokasi magnesium dari plasma ke dalam sel darah merah. ${ }^{8}$

Faktor-faktor lain yang juga berpengaruh yaitu faktor usia yang semakin tua, tidak berfungsinya ginjal dengan baik, asupan gizi yang tidak seimbang. ${ }^{3,4,9}$ Beberapa penyakit kronik juga bisa membuat kadar magnesium dalam tubuh menjadi rendah. ${ }^{10}$

Pada satu responden dengan kadar magnesium serum dalam tubuhnya rendah, hal ini bisa terjadi karena usia responden yang sudah mencapai 51 tahun. Usia yang semakin tua bisa menyebabkan kadar magnesium berkurang karena absorpsi magnesium di usus menurun dan ekskresi magnesium meningkat. ${ }^{3}$ Hipomagnesemia bisa terjadi karena pekerjaan responden yang termasuk aktivitas fisik intensitas berat yang membuat tubuh membutuhkan magnesium lebih, dan ditambah dengan asupan magnesium melalui makanan yang tidak dapat memenuhi kebutuhan gizi tubuh. $^{9,12}$ Keadaan responden yang mengerjakan pekerjaan berat tidak diimbangi dengan asupan yang seimbang dan kebiasaan mengonsumsi alkohol bisa menyebabkan kadar magnesium rendah. ${ }^{3}$

Sebanyak 29 responden memiliki kadar magnesium serum normal. Jika dibandingkan dengan beberapa penelitian mengenai kadar magnesium terhadap aktivitas fisik, hasil yang didapat akan ditemukan kadar magnesium yang rendah, tetapi sebagian besar hasil dinyatakan normal. Kadar magnesium normal pada penelitian ini bisa dipengaruhi oleh kebiasaan makan dan minum, jenis asupan makanan sehari-hari, tidak ada penyakit kronik yang diderita, dan tidak mengonsumsi obat-obatan yang memengaruhi kadar magnesium tubuh. Berdasarkan kuesioner yang diisi oleh responden yang mendapatkan hasil normal tidak didapatkan penyakit kronik yang memengaruhi kadar magnesium dalam tubuh seperti gagal ginjal, tidak ada riwayat penggunaan obat-obatan yang memengaruhi kadar magnesium, dan responden memiliki kebiasaan makan yang baik serta asupan yang cukup untuk memenuhi kebutuhan magnesium tubuh. ${ }^{12}$ Faktor lain yang bisa membuat hasil yang didapatkan normal karena variabel untuk pemeriksaan kadar magnesium hanya dilakukan dalam serum, distribusi magnesium dalam serum hanya sekitar $0,3 \%$ di tubuh manusia dan $99,07 \%$ sisanya ada di bagian lain dalam tubuh manusia., ${ }^{43}$

\section{SIMPULAN}

Berdasarkan hasil penelitian terhadap 30 pekerja bangunan di Fakultas Kedokteran Universitas Sam Ratulangi dapat disimpulkan bahwa sebagian besar 
pekerja memiliki kadar magnesium serum normal.

\section{SARAN}

Melalui penelitian tentang kadar magnesium serum terhadap pekerja bangunan maka peneliti menyarankan :

1. Untuk responden dengan kadar magnesium yang normal dianjurkan untuk mempertahankan melalui asupan yang cukup dan pola hidup yang baik.

2. Untuk responden dengan kadar magnesium yang rendah dianjurkan untuk memperhatikan asupan yang cukup dan pola hidup yang baik. Disarankan juga untuk kontrol lebih lanjut.

3. Penelitian yang akan datang dapat menggunakan sampel yang lebih banyak dan juga hasil dapat dikonfirmasi dengan kadar dalam urin.

\section{DAFTAR PUSTAKA}

1. Linder MC. Biokimia Nutrisi dan Metabolisme. Parakkasi A, translator. Jakarta: Universitas Indonesia (UI-Press), 1992. 759-781 p.

2. Horne MM, Swearingen PL. Keseimbangan Cairan, Elektrolit dan Asam Basa. Jakarta. EGC. 2001. 125 p.

3. Bhuto A, Mastoi AA, Memon SA, Qureshi GA, Qureshi AA. Magnesium and Its Essential Role in
Health.JLUMHS. 2005: p. 33-34.

4. Jahnen-Dechent W, Ketteler M. Magnesium Basics. Caburg: Clin Kidney J (CKJ). 2012.

5. Gum JG. Magnesium in Cardiovascular and Others Disorders. 2014;15: p. 1569-76.

6. Almatsier S. PrinsipDasar Ilmu Gizi. Jakarta: PT. Gramedia Pustaka Utama. 2003.

7. Rayssiquier Y, Guezennec CY, Durlach J. New Experimental and Clinical Data on the Relationship between Magnesium and Sport. 1990. Dapat diakses di http://www.ncbi.nlm.nih.gov/pubmed

8. Lukaski HC. Magnesium, Zinc, Chromium Nutriture, and Physical Activity. The American Journal of Clinical Nutrition. 2000 Agust;72(2): 585-593 $\mathrm{p}$.

9. Topf JM, Murray PT. Hypomagnesemia and hypermagnesemia. Rev endoc metab Disord 2003. p. 195-206.

10.Suzanna I, Anggraini I. The Reference range of serum, plasma, and erythrocyte magnesium. Jakarta: Medical Journal of Indonesia. 2006.

11.Rompas GR, Kaligis SHM, Tiho M. Perbandingan Magnesium Serum Sebelum dan Sesudah Aktivitas Fisik Intensitas Berat. Manado: eBm. 2015.

12.Hartwig A. Role of Magnesium in Genomic Stability. Mutat Res. 2001;475(1-2):113-21.

13.Swaminathan R. Magnesium Metabolism and its Disorder. Clin Biochem Rev. 2003;24 : p.47-61. 